Review

\title{
The Architect and the Paradigms of Sustainable Development: A Review of Dilemmas
}

\author{
Wojciech Bonenberg and Oleg Kapliński * \\ Faculty of Architecture, Poznań University of Technology, Nieszawska Str. 13C, 60-965 Poznań, Poland; \\ wojciech.bonenberg@put.poznan.pl \\ * Correspondence: oleg.kaplinski@put.poznan.pl; Tel.: +48-61-665-3260
}

Received: 20 December 2017; Accepted: 30 December 2017; Published: 3 January 2018

\begin{abstract}
This article presents the architect's attitude towards the paradigms of sustainable development. The place and role of the architect in the implementation of the multidimensional processes of sustainable design are presented. Basic dilemmas and antinomies are presented. The analysis of architects' attitudes towards these problems is performed in various contexts, examining the architect's awareness and his/her environment in view of changes under way. The article draws attention to the status of knowledge, changes in design paradigms, legislative and organizational requirements. The importance of architectural culture level, the need for training and ways to support the implementation of new design paradigms through integrated activities are indicated. The research results, regarding public awareness of architecture and sustainable development, are illustrated, with examples from Poland.
\end{abstract}

Keywords: architect; sustainable architecture; paradigms of design; knowledge; society; Poland

\section{Introduction}

The results of developing sustainable architecture are founded on the symbiosis of ecologists and architects. It began with these two professional groups proposing a change in the function of the building, i.e., a transition from a linear approach to a closed circulation plan. Therefore, from an ecological point of view, the plan of the building function has become a paradigm.

In a linear pattern, the building is treated as a "place of processing natural resources into waste". For example, energy is "converted" into heat losses, clean water into sewage, fresh air is converted into used air, materials and consumer goods into classical waste.

In a closed circulation plan, a building may change from a voracious consumer of energy and all other resources, into a more self-sufficient unit. It will be possible to use much less energy for heating in winter, and cooling and ventilation in the summer (part of the energy will be recovered). Part of the water can not only be saved, but also re-used. Generally, a large amount of waste can be avoided altogether, or used again.

The transition from one plan to another is evolutionarily. The first step in this design trend was passive, low energy buildings. The next step was friendly buildings-friendly not only for people, but also for the environment. Today, we are talking about almost zero energy buildings, autonomous buildings, and IQ architecture. There are numerous examples of such buildings. The shape of The Edge, a new office building in Amsterdam, described as the most modern and the most "green commercial building" in the world, is quite unusual. It was included in the category of intelligent buildings and, as part of the BREEAM (Building Research Establishment Environmental Assessment Method) certificate; in 2016, the building then scored a record value of $98.36 \%$ (on a scale from 0 to $100 \%$ ). Only two years after its construction, two more office buildings scored even higher: Bloomberg's new European headquarters in London (which scored 98.5\%) and the Geelen Counterflow Office in Haelen (The Netherlands) which scored 99.94\% [1-3]—of course, all in the Offices—New category. 
However, there are also examples of achieving spectacular success in the area of designing sustainable settlements or cities. Such an example is the city of Masdar in the Abu Dhabi emirate, together with the Masdar Institute of Science and Technology, which is autonomous in terms of energy. Moreover, it meets all other criteria of sustainable development.

Arriving at sustainable design is a continuous process. What consequently changes is the architect's attitude towards the design paradigms, which are particularly noticeable in the context of the intellectual and ecological revolution.

Society was, or has been a witness to, three revolutions, which have significantly influenced architecture. The industrial revolution in the late nineteenth century (replacing physical labour with machines) was a foundation of two other revolutions: the information and administration revolution (from the mid-twentieth century: information processing, strengthening mental abilities) and sustainable development type revolution, embracing aspects of ecology, economics and social/cultural values. This has been accompanied by enormous progress in the field of digitisation. All these revolutions are developmental in character, but one can also say that their derivative is a new term: architectural IQ. The dynamics of new examples/practical implementation of designs is amazing. One perhaps cannot understand the essence of the revolution-especially the sustainable development type-but, in design, it is obligatory to adapt to applicable law [4]. Unfortunately, the understanding of the paradigms of sustainable development and design paradigms in some social groups, including some architects, still produces some difficulties—dilemmas arise; there are contradictions in the interpretation of rules.

According to the authors, the key to solving these dilemmas is knowledge (its acquisition, broadening the scope), which will strengthen the understanding and application of the above-mentioned paradigms. Sometimes resistance to sustainable design is evident. The source of reluctance is limited awareness by part of the public as well as a certain group of architects.

The article deals with the architect's attitude towards these problems, examining the architect's awareness in different contexts, and his/her environment in the light of the changes under way. The results of research on the public awareness have been illustrated with examples from Poland. In addition, a review of the literature [5] indicates that there exists abundant studies in the sphere of sustainable development, but few in the area of the analysis of architects' attitudes in the face of changes in design, and ways of design (see also [6-8]).

\section{Explicit and Tacit Knowledge}

Many renown architects began their education and professional careers under the influence of modernism, which, in the 1980s, significantly impacted the approach to architectural and urban design. The difference in the level of knowledge prevailing in that period, and the knowledge necessary to understand and implement the principles of sustainable development, is enormous. The condensation of problems and new elements of knowledge faced by the architect today is quoted, in part, in Figure 1.

The quoted set of knowledge elements indicates that design is a team game, that, in order to cope with, you need a competent team at hand and new organizational methods should be used (e.g., integrated design), new tools (e.g., Building Information Modeling).

In designing, and from the architect's point of view (and his/her office), two types of knowledge are distinguished: formal (explicit knowledge) and hidden (tacit knowledge). Explicit knowledge is acquired; it stems from standards, technical design conditions, and can even be obtained from technical specifications. It also includes design paradigms. Tacit knowledge refers to individual skills, creativity, and is used on a regular basis in designing. Both types of knowledge constitute intellectual and creative capital [9]. 


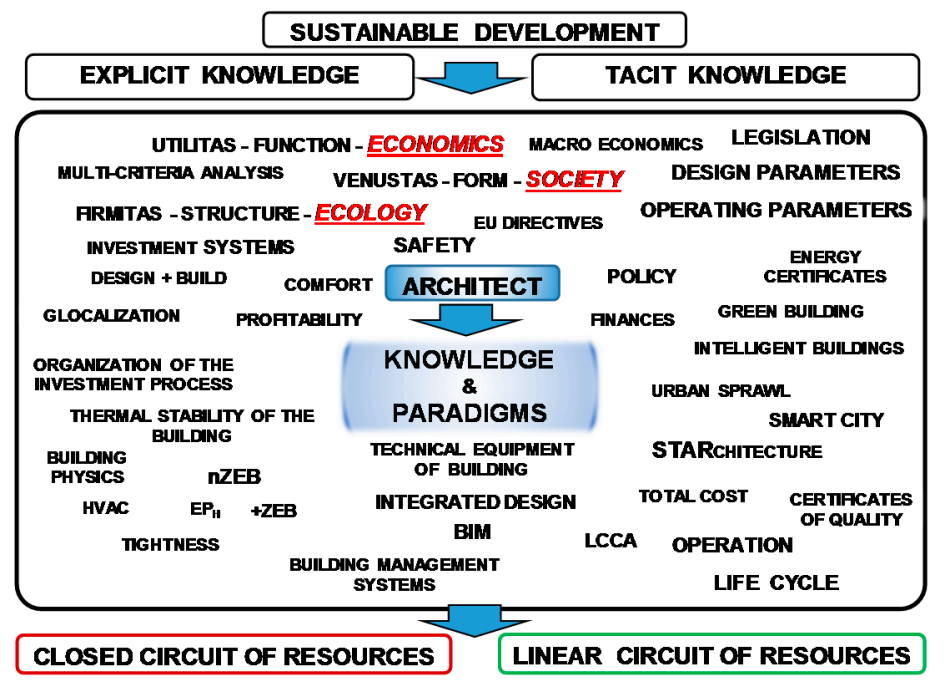

Figure 1. Typical dilemmas in the interaction of knowledge—-design paradigms—sustainable development.

An architect who is unable to use the elements of knowledge supporting sustainable design (Figure 1) loses not only his/her prestige, but can also make technical mistakes and become vulnerable to conflicts with the participants of the investment process [10-12]. Figure 1 has been supplemented with two contrasting patterns of the function of buildings (closed and linear circulation), which are at the basis of ecological design.

\section{Basic Legislative Requirements}

Design paradigms require permanent extension of knowledge. Legal acts accompany this process. As early as 1987, under the UNESCO patronage, a specific message for the architect was formulated, i.e., suggesting that the architect-taking into account the three criteria below-turn his/her attention to the beneficiary; that is, that he contributes to a fully balanced model of life. These criteria consisted of emphasizing the integration of activities in three areas: economic growth and an even distribution of profits, natural resources and protection of the environment and social development.

Further initiatives in this area were taken over by the European Parliament and the Council of Europe, in particular through the Commité Européen de Normalisation (CEN/TC 350), (cf. [13]). Subsequent acts tried to structure a number of issues related to sustainable development in construction; however, it has quickly turned out that designing buildings in accordance with these principles is not easy and, above all, requires a holistic, integrated approach. This results from the multitude of parameters defining the impact of the building on the three pillars of sustainable development: environment, society and economy. Therefore, a number of documents, developed by CEN/TC 350, have seeked to organize matters. The architect has been advised to design buildings that would not be burdensome for the natural environment, would meet conditions of comfort for users, and are at the lowest possible costs during the entire life cycle of the structure.

According to CEN/TC 350 and national standardization committees (e.g., in Poland, KT PKN 307, cf. [14]), the architect should take into account three basic areas, supported by the following standards:

- the area of environmental assessment,

- the area of social evaluation,

- the area of economic evaluation.

This section is divided by subheadings. It should provide a concise and precise description of the experimental results, their interpretation as well as the experimental conclusions that can be drawn.

The standards for assessing the impact of a building on the natural environment are determined by four groups of impacts, i.e., 
- parameters defining environmental interactions (including six quantifiable parameters),

- parameters defining the consumption of resources (including 10 quantifiable parameters),

- parameters regarding the amount of waste generated during the life cycle of a product or building (including three quantifiable parameters),

- parameters included in the LCA (Life Cycle Assessment) assessment, so-called output streams (including three quantifiable parameters).

This multitude of regulations favours the idea of sustainable architecture; however, it raises anxiety among designers. There are, however, indications which have the traits of imperatives. Indeed, in the last few years, the architect (and other entities of the investment process) collided with two very important requirements. They have a clear social and economic dimension.

The first of these results in requirements from the introduction of decisive instruments regarding sustainable policy, such as buildings with a demand for energy close to zero. This is a result of the 2002/91/CE EU Directive, amended in May 2010. This directive entered into force, for example in Poland, on 8 July 2010. The reality is that after 31 December 2018, all new buildings, used and owned by state administration, are to be designed/erected as buildings with almost zero energy consumption; however, after 31 December 2020, all new buildings are to be almost zero energy buildings ("nZEB").

The second very important requirement results from the 2010/31/EU Directive and national standards (e.g., PN-EN 15459). The requirement applies to the calculation period of the building's value (not as of today, but in a time perspective). A calculation period of 30 years has been introduced for residential and public buildings, and 20 years for non-residential buildings used for commercial purposes. This forces designers to become acquainted with such terms as Life Cycle Cost (LCC), Life-Cycle Cost Analysis (LCCA) and, above all, costs generated in the operation phase.

Both the 2010/31/UE Directive and the (EU) Commission Delegated Regulation No 244/2012 clearly indicate that the procedure for determining the "nZEB" standard must be based on economic calculations including the total cost. Total costs account for the sum of the net present value of the initial investment costs (Net Present Value, NPV), the sum reflecting maintenance and operating costs, as well as the costs of removal (liquidation of the investment). In order for the building assessment results to be comparable, a discount rate of $3 \%$ was adopted. This means the end of using the term "low investment costs", which, unfortunately, still functions in some countries as a criterion for evaluation, especially in public tenders. Incidentally, a discount rate of 3\% is appropriate for EU countries with stable economies. It is at least twice as high in Polish conditions.

The introduction of the abovementioned legislative requirements has highlighted two characteristic phenomena.

Firstly, there is a permanent paradox to be observed, especially in Central and Eastern Europe: in the coming years: the "nZEB" standard of designing will apply, while the energy standard of about 10 million apartments in Poland is lower than $240 \mathrm{kWh} / \mathrm{m}^{2}$. This information is sensitive, indicating a low level of environmental culture. However, at the same time, one can take an optimistic view of this problem: there will be jobs for our graduates owing to the expected modernization of many buildings.

Secondly, the introduction of the sustainable development paradigm resulted in a significant increase in demand for knowledge of physics of buildings. Only in this way can one explain myths and common opinions about, for example, the so-called glass houses (glass architecture), thermos buildings, breathing buildings, $\mathrm{CO}_{2}$ emission, tightness, etc. Unfortunately, what is needed on top of that, is detailed knowledge about heat transfer (another aspect is the accumulation mass of the building), knowledge about air exchange, moisture sorption, water vapour diffusion, the role of ventilation, etc., which are more and more often noticed during various conferences (cf. [15-19]).

\section{Integration of Creative Processes on the Path to Attaining Integrated Design}

It is standard to start teaching architecture from a presentation of the Vitruvian triad, which presents the perfection of architectural work as the balance between durability, usability and 
beauty (Firmitas, Utilitas, Venustas). Meanwhile, it is L.H. Sullivan's motto which is closer to our times: Form follows Function, nowadays transformed into Form follows Energy-the perspective of perceiving architecture changes, especially in the context of sustainable development. Another maxim results from three premises: ecology, economy and society. This triad is shown on the right hand side of Figure 2, as the green triad. The drawing also presents the pathological (though contemporary) black triad, namely: space, politics and money.

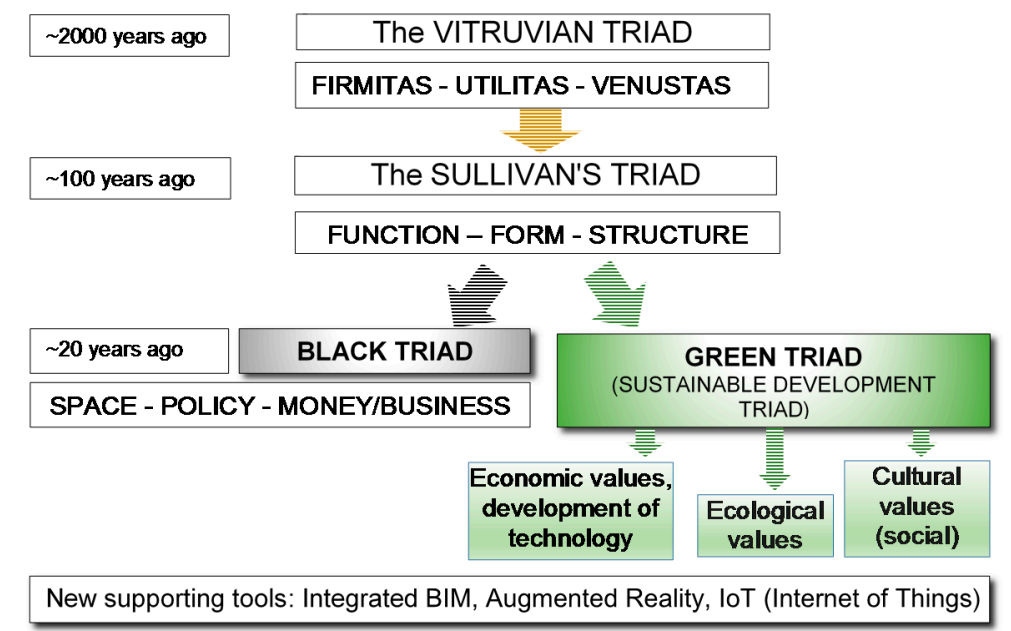

Figure 2. Architectural design paradigm triads.

One could ask the ironic question: which path to choose? Of course, none of the architects will officially dare to support any other triad but the one on the right (the green triad), on the other hand, why are there so many cases in Poland resulting from the black triad? Examples can be found in almost every country, where architectural services do not honour their obligations. One of the drastic examples is the gigantic "Univermag" in Zakopane in the historic Krupówki Street, blocking the view of the Tatra Mountains. How could an architect possibly match the notion of genius loci or context of the place with such a situation?

Several paradigms can be mentioned in the framework of sustainable design. One of them is a paradigm based on characteristic (target) parameters, which is a function of design (permanent) parameters and operational (variable) parameters. This approach is emphasized in the reverse aspects of design [20], and within architechnology. This intellectual trend gave rise to the paradigms of designing energy-efficient buildings, and then, "smart buildings". Today, the term architectural IQ already exists, and architectural IQ may be measured by an additional criterion, i.e., the building's capability of adapting changes occurring not only in the internal, but also in the external environment.

Within the framework of environment-friendly approach to architecture, the building analysis should be applied throughout its entire life cycle. Architects call this "from cradle to grave".

Under the new regulations, the application of the rule of low investment costs has been eliminated in favour of total costs. No documentation which does not specify the value of the building in the time span of 20 or 30 years can leave the architect's design office. This dimension was also adopted in Poland; the authors of this article believe that this period is too short, because at this time there may yet be no repairs, replacement of doors and windows, etc.

The next paradigm of sustainable policy mandates that, within either a year or three years, buildings must be designed with a demand for energy close to zero. The dates depend on the form of ownership.

The architect entered the twenty-first century with the changing paradigm of designing from linear (traditional) to integrated. The linear process is characterized by the division into industry disciplines, joining in, one after another, to the implementation of project documentation. In retrospect, 
it can be determined that such mode of design certainly gives a visual effect (aesthetic, [21]), but it often leads to ineffective energy performance of the created works, not to mention high operating costs and debatable impact on the environment.

The American Institute of Architects (AIA) has created a new type of contract, used for the implementation (design) of construction projects, called the Integrated Project Delivery (IPD), [22]. Integrated design is an iterative and interactive process, a way of implementing the entire investment process, which, in a rational (almost optimal, [5,23-27]) manner, in terms of cooperation of the project team-which includes the architect, the industry, the investor, the contractor and the user-allows creation of a balanced object from the viewpoint of construction and operating costs.

When comparing both design processes, it can be determined that the linear process is characterized by the separation of creative processes, while the integrated design is characterized by the integration of creative processes. The next stages of integration of creative processes-i.e., departing from the separation of these processes-are presented in a synthetic way, in Figure 3. Integrated Project Delivery (IPD) clearly promotes sustainable architecture.

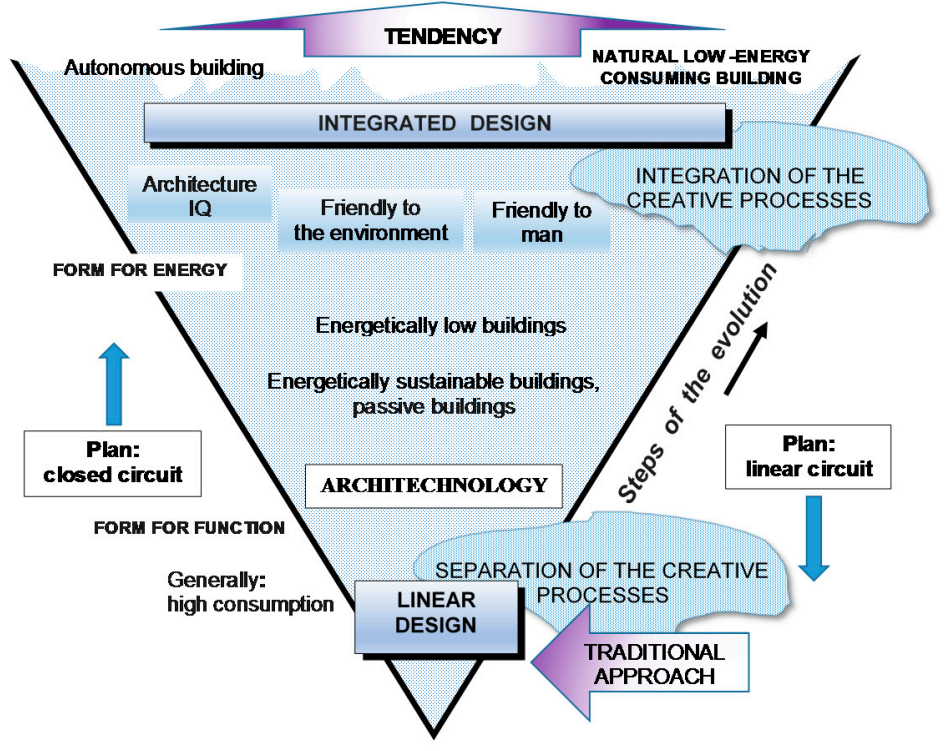

Figure 3. A reverse pyramid of the integration of creative processes in the process of achieving integrated design.

In some countries, this way of investing is underestimated. The most important limitation is inadequate legislation governing the organization of the investment process. Independent research [28,29] points directly to two important limitations: the shortage of specialists and experts from many disciplines who would understand architecture and the design process and the shortage of architects who would be prepared to run an integrated project team and to act as moderators/leaders of such a team. In countries such as Poland, there is a structural constraint, which is still important: the 2015 BCMM's research [30] shows that currently small-scale offices, employing up to three architects, dominate the structure of architectural office management in Poland, taking the share of up to three-quarters of the market. The following questions have arisen: How can we implement digital design technologies in such small teams? How can these small teams adapt to the canons of integrated design? How can we prevail over broadly-understood competition?

\section{The Architect's Attitude towards Antinomic Situations}

In his/her professional practice, the architect encounters various conflicts, not only administrative and substantive, but also squabbles with contracting parties and users. In the aspect of sustainable 
development, first and foremost, the architectural versus energy conflict is visible. It is a functionalspatial, usage related, financial and aesthetic conflict.

Architectural design is known for the need of compromise, especially in the context of energy criteria-functional and architectural needs-and increasing the insulation of external partitions. A typical, though a more specific conflict, is the relationship between the surface to volume of the building (A/V ratio) and a flat's or office's access to natural light, including the issue of terms of self-shading. It is known that the smaller the $\mathrm{A} / \mathrm{V}$ ratio, the more compact the building is and the lower the heat loss. Unfortunately, in our Eastern European climate, it is not possible to achieve a passive standard for an $\mathrm{A} / \mathrm{V}$ ratio exceeding 0.7. Studies have shown that an increase in the value of the A/V ratio by 0.1 means an increase in the external surface of the building in relation to its volume, and higher heat losses. To compensate for this, it is necessary to increase the thickness of the thermal insulation of an opaque barrier by around $3 \mathrm{~cm}$ [31]. This can explain why this coefficient is close to one in this part of Europe.

All this meant that originally passive buildings erected in some European countries, including Poland, were designated as "zeroarchitectural". Practice has shown something different, and splendid constructions were built. Moreover, the additional costs of the passive standard in Austria and Germany no longer exceed 4-6\%, so they have dropped from around 20\%, according to the Passive House Institute (PHI), in Darmstadt [32]. Most architects seek mitigation and even elimination of architectural and energy conflicts in Integrated Project Delivery (see e.g., [33-36]).

In this context, one of the architect's characteristic attitudes is quite noticeable. If there are no explicitly defined endpoints in the contract (in the requirements laid out by the contracting authority, or in the technical specifications), the architect will only prefer functional and architectural solutions, and is not guided by the energy prerogatives resulting from sustainable development. In this case, such an attitude does not result from the architect's ignorance of, but from, conformism. In the age of sustainable development, should an architect not promote innovative solutions as part of his/her mission? (See [4,6-9]).

Almost simultaneously with the concept of sustainable architecture, the concept of STARchitecture or STAR-architecture appeared. This describes emotional, star and media oriented architecture, in need of publicity (and the architect's success) and, unfortunately, often lacking the features of pro-ecological architecture. From the point of view of sustainable development, in most cases, this is a poorly-understood success. These types of buildings can be assessed (and compared on the backdrop of already-developed criteria used in certificates, e.g., BREEAM, LEED.) Unfortunately, data from this field are reluctantly disclosed. A positive example is the Edge building, mentioned above.

In the last few years, structures have emerged expansively, which can be attributed to the definitions of biomorphic, bionic or biomimetic architecture. The examples are excellent: the Zayed National Museum-called the desert sculpture in the United Arab Emirates (Foster \& Partners, Figure 4a); Callebaut's stone mounds in China (Figure 4b) and the Ordos Museum—called the high tech bionic dune in Inner Mongolia (Chinese MAN design office, Figure 4c). The question arises whether bionic or biomorphic architecture is, by definition, sustainable architecture? We have to be very careful providing the answer, because bio-objects must meet the classic conditions assigned to sustainable architecture. Some see this type of architectural solution as a vehicle securing the status of sustainable architecture. Bio is not, by definition, a fully sustainable architecture, but it is certainly interesting. In STAR architecture, anti-smog architecture has emerged in a good context, for example "Anti Smog: An Innovation Centre in Sustainable Development" in Paris. V. Callebaut's building, is now an example of sustainable design (Figure $4 \mathrm{~d}$ ). The building, equipped with vertical axis wind turbines, due to financial reasons, has, unfortunately, not been built. 
a)
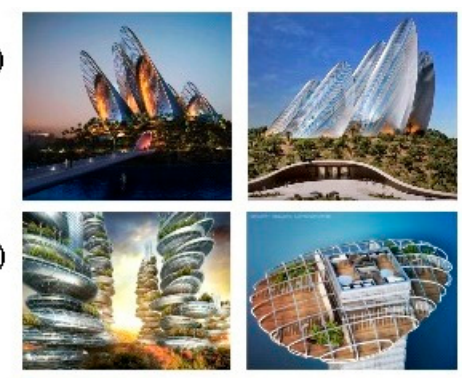

c)
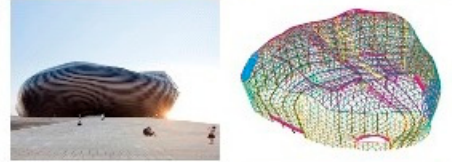

d)
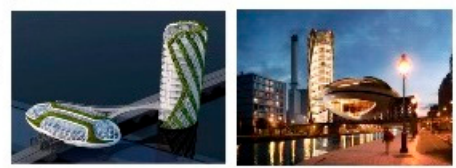

Figure 4. Examples of bio-type architecture (sources [37-43]). (a) The Zayed National Museum; (b) Callebaut's stone mounds; (c) The Ordos Museum; (d) Anti Smog: An Innovation Centre in Sustainable Development.

There is one more area of misunderstanding. The truth is that many designers limit sustainability to just designing a building. Spatial planning and urban planning are less often discussed in the context of sustainable development. From scanning through literature using web browsers, one can conclude that the number of articles on sustainable buildings is significantly higher than articles on sustainable cities. This ratio is 5:1. However, Smart City is more than just a sustainable building. The building is only part of the space. All the three pillars of sustainable development should be fully interpreted and applied, and, above all, the socio-cultural pillar [44,45].

There is also a counter-phenomenon, dangerous for sustainable development. It is the urban sprawl or sub- or ex-urbanization. This phenomenon is now recognized as the opposite of sustainable development. Urban sprawl is treated as a threat to a city's identity [46]. The reaction of the architectural community should be unambiguous.

\section{Professional Prestige and Identity of the Architect}

The symbolic scope of knowledge, as outlined in Figure 1, is indispensable for the architect, to allow conscious implementation of the paradigms of designing sustainable structures. However, it is extensive interdisciplinary knowledge, organizational skills and creative skills that predispose the architect to be a moderator in Integrated Project Delivery (IPD). These factors will determine the architect's competence. In turn, professional competences strongly affect the prestige of an architect. The role of universities and professional self-government is of great importance here. In all universities, academic curricula have been, or are being, modified (see good examples [47,48]). The reactions of professional self-government organizations of local architects' engineers, supported by editorial boards of trade magazines are satisfactory. Examples include the Architects' Council of Europe (ACE) and the National Chamber of Polish Architects (IARP), see [49].

Apart from the need for intensive acquisition of knowledge, the architect is required to lobby for changes in legislation (adapted to changing paradigms and organization of design), even to become involved in marketing addressed to the general public in the field of architectural culture, and influencing the image of the profession. This also affects the professional prestige and identity of the architect, as illustrated in Figure 5. Explicit knowledge-increase of competences-of social interaction skills, means an increase in professional identity and a stronger impact on society and even 
on legislation. Hence, there are guarantees of high-quality of architectural space, and the practical use of sustainable development paradigms.

A graduate of the architecture department at the beginning of the course of studies should be aware that technical knowledge is rapidly aging. It requires continuous self-education: one cannot follow the routine. Broadly understood design paradigms change.

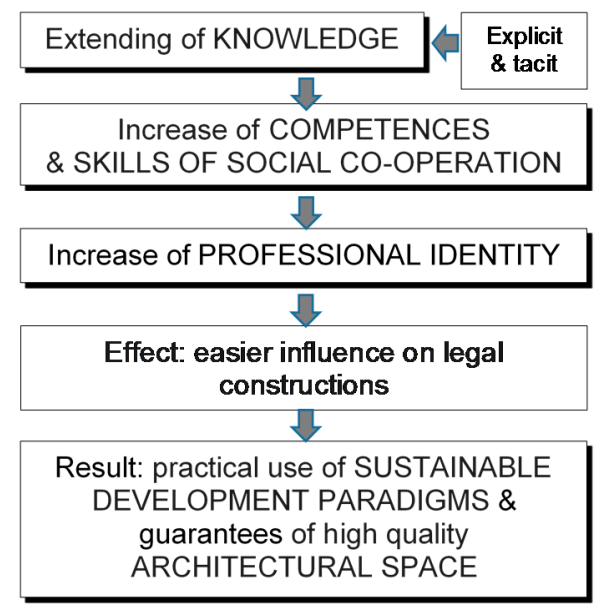

Figure 5. Prestige of the profession and identity of the architect in the context of sustainable development.

Unexpectedly, the architect's professional prestige is raised by BIM. BIM is an instrument which is expected to link sustainable construction with integrated design, and with a building's life cycle. $\mathrm{M}$ in this abbreviation means model, modelling and management. It is said that it is almost a revolution in managing large project projects. BIM technologies allow all participants of the process to access the same model of the building being designed at the same time. Therefore, designing in BIM is not only a change in software, but a change in the whole approach to the organization of investment and, above all, the design process. Conferences and even summits (e.g., [50]) take place in almost every country, concluding that the use of BIM definitely increases the prestige of design offices and contractors.

Tardiness is nothing out of the ordinary, though. Here is an example: as results from the research carried out in 2015, and the report [51], the awareness and use of BIM in Poland, compared to other countries, is not favourable. Nevertheless, awareness of its existence is noticeably higher in larger offices employing more than 10 people $(56.5 \%)$ and among younger people more focused on new design techniques, and this amounts to about 60 percent. At the same time, the respondents say that BIM awareness is higher among architects (65.4\%) than in other industries. Such a high level of awareness, though, is not the same as active use of this tool.

According to these studies, among the factors that slow down the development of BIM (in Poland), respondents mention the existence of a small number of specialists working with BIM $(71.4 \%)$, low awareness of benefits for investors $(68.9 \%)$, lack of shared operating standards $(68.9 \%)$, project prices that are too low $(83.9 \%)$ and, above all, reluctance to make changes in the methodology of design (61.5\%).

The element accelerating the implementation of BIM is the 2014/24/EU Directive of the European Parliament and of the Council of 26 February 2014. The Member States were supposed to implement this directive into their national legal systems by 18 April 2016. Some countries, including Poland, followed the British experience [52-54]. In Great Britain the preparations, lasting from 2008, were divided into four stages, and from 2016, BIM became obligatory for public investments [55]. Interesting remarks are also presented in $[56,57]$.

One thing is almost univocal: hope in the implementation of all these paradigms and instruments should be placed in architectural youth, better prepared for the profession. Moreover, the obligation to introduce BIM changes the structure of the design/investment market to a large extent. 


\section{Knowledge and Public Awareness}

The architect alone will not solve the above issues. Knowledge and public awareness are important for the success of the sustainable development program. Unfortunately, the international Dodge Data \& Analytics report [58] says that there are countries with diverse public awareness about the benefits of sustainable construction. The group of countries with the lowest awareness includes Colombia, Brazil, India and Poland. A similar contestation was provided by the RenoValue report. [59]. Most respondents indicated a lack of knowledge and support from the central administration or local governments as the main obstacle on the path of development of the sustainable market. Awareness alone will not help if there are no proper legal regulations [60].

Since the level of public awareness in individual countries cannot be consolidated, detailed considerations are focused on Poland. In 2015, the Public Opinion Research Centre (TNS OBOP) surveyed the knowledge of Poles about energy saving. It turned out that 86 percent of the subjects associated energy saving only with the reduction of electricity consumption, while as much as 71 percent of the energy is used by heating [61-63].

Architecture is not the subject of interest for the average Pole (though they declare it is), or, with few exceptions, of the leading media.

The low architectural culture of Poland undoubtedly results from complex, long-term historical processes, as well as the lack of basic knowledge about architecture and the importance of space for the community. The SARP Report (Association of Polish Architects) "Space of Polish life" [64] indicates that the reason for this state is also the lack of basic architectural education, which should be taught as part of the knowledge about the environment from kindergarten, and then enriched by incorporating architectural topics into art education in schools.

The opinions about green/sustainable buildings are characteristic. For most market participants, the most important characteristic of green buildings is energy saving: $95 \%$. A low percentage of respondents have noticed that sustainable construction does not only mean energy saving, but also improvement of well-being, health and reduction of absenteeism. The detailed Construction Marketing Group (CMG) report is uncompromising and exposes this situation (see [65], compare also [66-69]).

The research has shown how low the level of knowledge on the market is about the impact of sustainable buildings on the health and productivity of employees (CMG 2013) [67]. The perception of benefits of sustainable construction from the viewpoint of developers, investors and major tenants was examined. Fifty-four percent of respondents (the same number of companies) disagree or are uncertain about the statement that their company might be willing to incur higher costs of purchasing or renting a green building, in order to provide their tenants or employees with a healthy workplace.

In the United States, absences due to health problems cost companies several hundred to even 2500 dollars per employee per year [70]. Green solutions help to significantly reduce the number of absences caused by illness and offset these losses by up to $40 \%$. Also, according to European Union research, sustainable construction significantly improves the health of employees, which is evidenced by a smaller number of sick leaves (35-55\%), [71]. However, sustainable development aims to ensure a proper balance between concentration and communication. This is important, because of the efficiency of employees and their well-being.

CMG also conducted studies in the area of cost awareness. The results are rather optimistic. Only $8 \%$ of respondents pointed to an increase in the cost of sustainable construction by $15-20 \%$, while the majority (38\%) indicated a $5-10 \%$ increase in costs. As to the reasons for the higher costs of erecting a sustainable building, developers, first of all, referred to costs related to the use of modern technologies (according to $87 \%$ of responses, this is a "strong" or "fairly large" impact). However, as many as three-quarters of the surveyed developers believed that the excess costs associated with the design and construction of a green building will decrease in the future. This shows that developers are convinced that these are prospective investments.

The above review does not yet provide a full picture of the public awareness of sustainable development and architecture. Therefore, it is worth quoting excerpts from two CBOS (Public Opinion 
Research Center, Poland) surveys (2013 and 2014) [72] about the awareness of architecture and the architects' work. The results are surprising:

- Twenty-four percent of adult Polish residents have not seen any city abroad, and together with those who saw one or two cities, this makes one-third of the population of respondents;

- One-third acknowledge that they are not interested in it at all (i.e., architecture);

- The answer to the question of how the knowledge of architecture is obtained prodded answers which the architects have never taken into consideration, namely, TV series and other TV programs. After rejection of negative votes, the sum of responses regarding TV series and TV accounted for $23 \%$, but it was the Internet that prevailed (25\%). This case is illustrated in Figure 6.

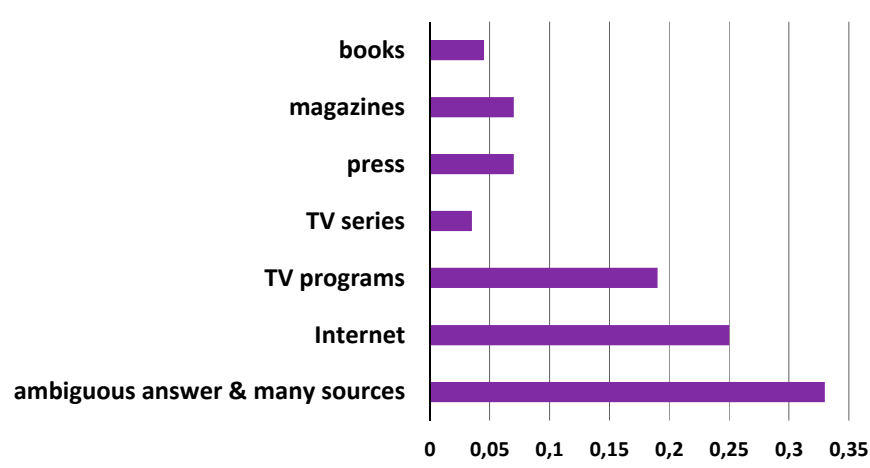

Figure 6. Answers to the question of 'Where do you get the knowledge about architecture (after rejecting negative answers?'

According to earlier CBOS surveys, performed in 2013, as many as $62 \%$ of respondents believe that "everyone should be able to build a house that they like" [73]. From these studies, the inability to verbalise feelings and assessments of architecture came to light [74,75].

The quoted surveys and reports rise concern about architectural culture. At the same time, the hermeticity of knowledge is emphasized and there is a lack of discussion about the social effects of the designed structures $[36,64]$. A clear position is contained in the "The Poles Living Space" SARP Report [64], emphasizing the urgent need for education, also in the area of sustainable development, so that raising public awareness of architecture and sustainable development does not take place under the dictate of TV series.

In this context, the attitude of architecture faculty students becomes extremely important [76]. Designers/practitioners place their hopes in graduates who they hire, expecting that they have basic knowledge of building physics and energy efficiency. Unfortunately, as they have stated in the professional press, these hopes are shattered [77].

The issues of low architectural culture cannot be taken lightly. Shaping public awareness is primarily a mission of architects, but their own knowledge and awareness are becoming a strategic element of the success of the idea of sustainable development.

\section{Conclusions}

Implementation of the sustainable development process entails changes in design standards, and is dependent on both the public's, and the architect's, awareness. The significance of knowledge is increased intentionally, including the understanding of changes in design paradigms.

Unfortunately, the presented surveys indicate a low level of architectural culture (based on the example of Polish residents), as well as insufficient knowledge about the essence of sustainable development. 
This phenomenon must not be underrated. Shaping public awareness is, above all, a mission of architects; their knowledge and awareness become a very important strategic element of the success of the whole idea, because the architect's perspective must always be wider and multidimensional.

The synergy of action for legislative changes, implementation of new technologies, raising the level of knowledge and, a change in public awareness will guarantee the success of architecture in the process of sustainable development.

Acknowledgments: The authors wish to thank the Institute of Architecture and Spatial Planning at PUT for its financial support.

Author Contributions: All authors contributed equally to this work.

Conflicts of Interest: The authors declare no conflict of interest.

\section{References}

1. Wang, L. Bloomberg's New London HQ Rated World's Most Sustainable Office. Available online: https:/ / inhabitat.com/bloombergs-new-london-hq-rated-worlds-most-sustainable-office/ (accessed on 15 November 2017).

2. Best of BREEAM 2017 Exceptional Sustainable Places and Project Teams from the BREEAM Awards 2017. Available online: http://www.breeam.com/filelibrary/BREEAM\%20Awards/BREEAM-Awards-2017/ BREEAM_Awards_Brochure_-1061-.pdf (accessed on 15 November 2017).

3. Best of BREEAM 2016 Outstanding Sustainable Buildings from the BREEAM Awards 2016. Available online: http:/ / www.breeam.com/filelibrary/BREEAM\%20Awards/109611_Best_of_BREEAM_Awards_ 2016_WEB.pdf (accessed on 15 November 2017).

4. Bonenberg, W.; Kapliński, O. Postawa architekta wobec zrównoważonego rozwoju. In Architektura Wobec Wyzwań Zrównoważonego Rozwoju; Poznan University of Technology Press: Poznań, Poland, 2016; Volume 2, pp. 11-30. ISBN 978-83-7775-438-2.

5. Ubarte, I.; Kapliński, O. Review of the sustainable built environment in 1998-2015. Eng. Struct. Technol. 2016, 8, 41-51. [CrossRef]

6. Baranowski, A. Projektowanie Zrównoważone w Architekturze; Wyd. Politechniki Gdańskiej: Gdańsk, Poland, 1998.

7. Bać, A. Zrównoważenie w Architekturze. Od Idei do Realizacji na tle Dokonań Kanadyjskich; Oficyna Wydawnicza Polit. Wrock.: Wrocław, Poland, 2016.

8. Kronenberg, J.; Bergier, T. Wyzwania Zrównoważonego Rozwoju w Polsce; Fundacja Sendzimira: Kraków, Poland, 2010.

9. Bonenberg, W.; Kapliński, O. Knowledge is the key to innovation in architectural design. Procedia Eng. 2017, 208, 2-7. [CrossRef]

10. Belniak, S.; Leśniak, A.; Plebankiewicz, E.; Zima, K. The influence of the building shape on the cost of its construction. J. Financ. Manag. Prop. Constr. 2013, 18, 90-102. [CrossRef]

11. Dziadosz, A. The influence of solutions adopted at the stage of planning the building investment on the accuracy of cost estimation. Procedia Eng. 2013, 54, 625-635. [CrossRef]

12. Kapliński, O. An important contribution to the discussion on research methods and techniques in designing. Eng. Struct. Technol. 2015, 7, 50-53. [CrossRef]

13. Directive 2010/31/EU of the European Parliament and of the Council of 19 May 2010 on the Energy Performance of Buildings (Recast). 2010. Available online: http://eur-lex.europa.eu/legal-content/en/ TXT/?uri=CELEX:32010L0031 (accessed on 29 December 2017).

14. Polski Komitet Normalizacyjny. Energy Performance of Buildings-Economic Evaluation Procedure for Energy Systems in Buildings-Part 1: Calculation Procedures, Module M1-14; PN-EN 15459-1:2017-07E; PKN: Warszawa, Poland, 2017.

15. Bonenberg, W. Requirements engineering as a tool for sustainable architectural design. In Advances in Human Factors, Sustainable Urban Planning and Infrastructure; Charytonowicz, J., Ed.; Springer: Cham, Switzerland, 2018; Volume 600, pp. 218-227. ISBN 978-3-319-60449-7.

16. Januchta-Szostak, A.; Banach, M. Architektura Wobec Wyzwań Zrównoważonego Rozwoju; Faculty of Architecture, Poznan University of Technology: Poznań, Poland, 2016. 
17. Kapliński, O. Sustainable development and intelligent buildings as elements of humanization of technological civilization. In Technikos Humanizavimas, Humanizacja Techniki, Humanisation of Technology; Technika: Vilnius, Lithuania, 2001; pp. 225-231.

18. Koczyk, H.; Basińska, M. Optimum energetyczno-ekonomiczne rozwiązań instalacyjnych budynków energooszczędnych. In Budownictwo Energetyczne w Polsce-Stan i Perspektywy, Proceedings of the KILiW PAN \& KN PZITB Conference, Krynica, Poland, 27-28 May 2015; UTP-Bydgoszcz Press: Bydgoszcz, Poland, 2015; pp. 241-252.

19. Szczechowiak, E. Parametry budynków niemal zero-energetycznych w warunkach polskich. In Budownictwo Energetyczne w Polsce-Stan i Perspektywy, Proceedings of the KILiW PAN \& KN PZITB Conference, Krynica, Poland, 27-28 May 2015; UTP-Bydgoszcz Press: Bydgoszcz, Poland, 2015; pp. 57-68.

20. Rosolski, S. Projektowanie Architektoniczne a Zagadnienia Odwrotne; Exemplum: Poznań, Poland, 2012.

21. Crouch, C.; Kaye, N.; Crouch, J. An Introduction to Sustainability and Aesthetics: The Arts and Design for the Environment; Brown Walker Press: Irvine, CA, USA, 2015.

22. The American Institute of Architects; American Institute of Architects California Council. Integrated Project Delivery: A Guide; version 1National California Council: San Francisco, CA, USA, 2007.

23. Kaklauskas, A.; Zavadskas, E.K.; Dargis, R.; Bardauskiene, D. Sustainable Development of Real Estate; Technika: Vilnius, Lithuania, 2015.

24. Zavadskas, E.K.; Antucheviciene, J. Development of an indicator model and ranking of sustainable revitalization alternatives of derelict property: A Lithuanian case study. Sustain. Dev. 2006, 5, 287-299. [CrossRef]

25. Zavadskas, E.K.; Antuchevicienè, J.; Kaplinski, O. Multi-criteria decision making in civil engineering. Part 1-A state-of-the-art survey. Eng. Struct. Technol. 2015, 7, 103-113. [CrossRef]

26. Zavadskas, E.K.; Antuchevicienè, J.; Kaplinski, O. Multi-criteria decision making in civil engineering. Part 2-Applications. Eng. Struct. Technol. 2015, 7, 151-167. [CrossRef]

27. Gajzler, M. Usefulness of mining methods in knowledge source analysis in the construction industry. Arch. Civ. Eng. 2016, 62, 127-142. [CrossRef]

28. Majerska-Pałubicka, B. Zintegrowane Projektowanie Architektoniczne w Kontekście Zrównoważonego Rozwoju. Doskonalenie Procesu; Silesia Technical University Press: Gliwice, Poland, 2014.

29. Perspektywy Rozwoju Budownictwa Energooszczędnego w Polsce. Zespół Go4Energy. Available online: http:/ /g4e.pl/wp-content/uploads/2014/05/Go4Energy_raport_wiosna_2014.pdf (accessed on 30 April 2016).

30. BCMM. Nastroje Architektów 2015. Wyniki Badania Sondażowego Wśród Architektów, Kwiecień 2015. Available online: www.bcmm.com.pl (accessed on 4 April 2016).

31. Laskowski, L. Ochrona Cieplna i Charakterystyka Energetyczna Budynku; Oficyna Wydawnicza Pol. Warsz.: Warszawa, Poland, 2005.

32. The Passive House Institute (PHI). Available online: http:/ /www.passiv.de/en/01_passivehouseinstitute/ 01_passivehouseinstitute.htm (accessed on 15 October 2017).

33. Bickert, E. Green Building, Sustainable Real Estate Investment, Sustainable Valuation \& Efficiency Assessment: Neue Projekte, Berichte und Leitfäden. Forum Nachhaltige Immobilien. Available online: https:/ / forumnachhaltigeimmobilien.com/2016/06/06/green-building-sustainable-real-estateinvestment-sustainable-valuation-efficiency-assessment-neue-projekte-berichte-und-leitfaeden/ (accessed on 1 June 2017).

34. Hegger, M.; Fuchs, M.; Stark, T.; Zeumer, M. Energy Manual. Sustainable Architecture; Birkhäuser: Basel, Switzerland, 2008.

35. Marchwiński, J. Konflikty architektoniczno-energetyczne w projektowaniu miejskich budynków wielorodzinnych. Ciepłownictwo, Ogrzewnictwo, Wentylacja 2014, 45, 10-14.

36. Niezabitowska, E.; Masły, D. Oceny Jakości Środowiska Zbudowanego i Ich Znaczenie dla Rozwoju Koncepcji Budynku Zrównoważonego; Silesia Technical University Press: Gliwice, Poland, 2007.

37. Zayed National Museum. Available online: https://www.e-architect.co.uk/dubai/zayed-national-museum (accessed on 1 June 2017).

38. Warmann, C. Zayed National Museum by Foster + Partners. Available online: https:/ /www.dezeen.com/ 2010/11/25/zayed-national-museum-by-foster-partners / (accessed on 1 June 2017). 
39. Sikora, A. Asian Cairns. Sustainable Farmscrapers for Rural Urbanity-Vincent Callebaut Architectes. 2013. Available online: http:/ / progg.eu/kamienne-kopce-callebauta-biomorficzna-architektura-w-bionicznymmiescie/ (accessed on 1 June 2017).

40. Kalogeropoulos, S. Vincent Callebaut Architectures: Asian Cairns, Shenzhen, China. Available online: http:/ / mydesignstories.com/vincent-callebaut-architectures-asian-cairns-shenzhen-china/ (accessed on 1 June 2017).

41. Frearson, A. Ordos Museum by MAD. Available online: https://www.dezeen.com/2011/12/13/ordosmuseum-by-mad/ (accessed on 1 June 2017).

42. Ordos Museum. Available online: https://en.wikiarquitectura.com/building/ordos-museum/ (accessed on 1 June 2017).

43. Kriscenski, A. Anti Smog Architecture: A Catalyst for Cleaner Air in Paris. Available online: https:// inhabitat.com/anti-smog-architecture-a-catalyst-for-cleaner-air-in-paris/ (accessed on 1 June 2017).

44. Bonenberg, A. Cityscape in the Era of Information and Communication Technologies; Springer: Cham, Switzerland, 2018; ISBN 978-3-319-69541-9.

45. Zhou, M.; Bonenberg, W. Application of the green roof system in small and medium urban cities. In Advances in Human Factors and Sustainable Infrastructure, Proceedings of the AHFE 2016 International Conference on Human Factors and Sustainable Infrastructure, Orlando, FL, USA, 27-31 July 2016; Walt Disney World: Orlando, FL, USA, 2016; pp. 125-136.

46. Bonenberg, W. Urban sprawl jako zagrożenie tożsamości miasta. Zeszyty Naukowe Politechniki Poznańskiej. Architektura i Urbanistyka 2011, 23, 7-14.

47. Alvarez, S.P.; Lee, K.; Park, J.; Rieh, S.-Y. A comparative study on sustainability in architectural education in Asia-With a focus on professional degree curricula. Sustainability 2016, 8, 290. [CrossRef]

48. Hassanpour, B.; Atun, R.A.; Ghaderi, S. From words to action: Incorporation of sustainability in architectural education. Sustainability 2017, 9, 1790. [CrossRef]

49. Architects' Council of Europe (ACE). The Architectural Profession in Europe 2016-ACE Sector Study. Available online: http:/ / www.ace-cae.eu/837 / ?L=0 (accessed on 3 November 2017).

50. The European Summit on BIM. Available online: http://europeanbimsummit.com/the-summit/ (accessed on 11 November 2017).

51. Raport BIM-Polska Perspektywa. Available online: www.ebuilder.pl/index.php?act=article\&sub=save\& id=9902 (accessed on 30 November 2015).

52. The British Standards Institution. Sustainability of Construction Works. Assessment of Environmental Performance of Buildings. Calculation Method; BS EN 15978:2011; The British Standards Institution: London, UK, 2011.

53. Bewa, M.; Richards, M. UK Government BIM Roadmap; RIBA: London, UK, 2008.

54. The British Standards Institution. Specification for Information Management for the Capital/Delivery Phase of Construction Projects Using Building Information Modeling; PAS 1192-2:2013, Incorporating Corrigendum No. 1; The British Standards Institution: London, UK, 2013.

55. Salamonowicz, M. BIM: Wdrożenie w Wielkiej Brytanii. Zawód:Architekt 2015, 11/12, 132-140.

56. Zima, K.; Leśniak, A. Limitations of cost estimation using building information modeling in Poland. J. Civ. Eng. Archit. 2013, 7, 545-554.

57. Juszczyk, M.; Vyskala, M.; Zima, K. Prospects for the use of BIM in Poland and the Czech RepublicPreliminary research results. Procedia Eng. 2015, 123, 250-259. [CrossRef]

58. Dodge Data \& Analytics. World Green Building Trends 2016; Smart Market Report; DODGE Data \& Analytics: Bedford, MA, USA, 2016.

59. Reno Value Report: Drivers for Change: Strengthening the Role of Valuation Professionals in Market Transition; Market Insights Report. EU: Brussels, Belgium, 2015. Available online: https:/ / ec.europa.eu/easme/sites/ easme-site/files/RENOVALUE\%20report\%20JUne\%202015.pdf (accessed on 1 November 2017).

60. Eko Budownictwo w Polsce Wciąż bez Wystarczającego Wsparcia Rządowego. Available online: http: / / beta.oswbz.org/wp-content/uploads /2015/12/Eko-budownictwo-w-Polsce-propertyjournal.pdf (accessed on 1 February 2016).

61. Competency Based Occupational Standards. Polacy o Oszczędzaniu Energii i Energetyce Obywatelskiej. Komunikat z Badań nr 36/2016. 2016. Available online: http:/ /www.cbos.pl/SPISKOM.POL/2016/K_036_ 16.PDF (accessed on 10 November 2017). 
62. Raport RWE Polska 2013 Świadomość Energetyczna Polaków. Available online: http://www. postawnaslonce.pl/pliki/wokol_energii_i_fotowoltaiki/Badanie_swiadomosci_Polakow / Raport_ Swiadomosc_Energetyczna_Polakow.pdf (accessed on 1 January 2017).

63. Analiza TNS Polska dla Ministerstwa Środowiska. Raport z Analizy Badań Świadomości, Postaw i Zachowań Ekologicznych Polaków Przeprowadzonych w Polsce w Latach 2009-2015. 2015. Available online: http: / / www.3xsrodowisko.pl/uploads/media/badanie_dr_ekologia_ministerstwo_srodowiska.pdf (accessed on 1 November 2017).

64. SARP Warszawa. Raport SARP: Przestrzeń życia Polaków; SARP Warszawa: Warsaw, Poland, 2014; Chapter I; pp. $145-170$.

65. Colliers International. Zdrowie i Produktywność w Zrównoważonych Budynkach; Construction Marketing Group: Warsaw, Poland, 2015.

66. Colliers International. Zielone Budynki w Polsce 2015; Building Consultancy Services, Green Building Certification: Warsaw, Poland, 2015.

67. Analiza Rynku Zrównoważonego Budownictwa w Polsce. Badanie Percepcji Rynku; Construction Marketing Group: Warsaw, Poland, 2013.

68. Polacy o Oszczędzaniu Energii w Budownictwie-Architekci, Inwestorzy. 6paliwo-Raport-2. Available online: http:/ / 6paliwo.pl/wp-content/uploads/2012/02/6paliwo-raport-2.pdf (accessed on 6 April 2017).

69. Raport RWE Polska 2013. Świadomość Energetyczna Polaków; Biuro Prasowe RWE: Warsaw, Poland, 2013.

70. Health, Wellbeing and Productivity in Offices: The Next Chapter for Green Building. Available online: http:/ / www.worldgbc.org/news-media/health-wellbeing-and-productivity-offices-next-chaptergreen-building (accessed on 24 September 2014).

71. Sick Pay and Sickness Benefit Schemes in the European Union. Background Report for the Social Protection Committee's. In-Depth Review on Sickness Benefits Brussels. Available online: Ec.europa.eu/social/ BlobServlet?docId=16969\&langId=en[KE-02-17-045-EN-N(1).pdf] (accessed on 17 October 2016).

72. Competency Based Occupational Standards. Polacy o Architektach. Komunikat z Badań nr 161/2014. Available online: http:/ / www.cbos.pl/SPISKOM.POL/2014/K_161_14.PDF (accessed on 10 November 2017).

73. Prośniewski, B. Gust Nasz Pospolity; Fundacja Bęc Zmiana: Warsaw, Poland, 2004.

74. Prośniewski, B. Anioł Najbardziej Przykuwa Moja Uwage-Czyli Polski Gust Architektoniczny. Zawód:Architekt 2015, 43, 39-45.

75. Osowski, S. Polacy o architektach w badaniu CBOS. Zawód:Architekt 2015, 43, 46-48.

76. Bać, A. Idea zrównoważenia i jej wybrane przejawy. Architectus 2014, 2, 3-14.

77. Mielczyński, T. Forma podąża za energia. Zawód:Architekt 2014, 38, 92-94. 